\title{
Comparison of air pollution and the prevalence of allergy-related diseases in Incheon and Jeju City
}

Su Ho Jeong, $M D^{1}$, Jeong Hee Kim, $M D^{1}$, Byong Kwan Son, MD', Seong Chul Hong, $\mathrm{MD}^{2}$, Su Young Kim², Geun Hwa Lee, Dae Hyun Lim, MD

${ }^{1}$ Department of Pediatrics, Environmental-Health Center, Inha University Hospital, Inha University School of Medicine, Incheon, Departments of ${ }^{2}$ Preventive Medicine and ${ }^{3}$ Microbiology and Immunology, Jeju National University College of Medicine, Jeju, Korea

Received: 15 September 2010, Revised: 3 January 2011

Accepted: 7 November 2011

Corresponding author: Dae Hyun Lim, MD

Department of Pediatrics, Inha University Hospital, Inha University School of Medicine, 7-206 Shinheung-dong 3-ga, Jung-gu, Incheon 400-711, Korea

Tel: +82-32-890-2843, Fax: +82-32-890-2844

E-mail: dhyunlim@inha.ac.kr

Copyright ( 2011 by The Korean Pediatric Society
Purpose: A high level of air pollutants can increase the number of patients with allergy-related diseases such as asthma and allergic rhinitis (AR). To analyze the association between air pollution and allergic disease, we investigated 2 areas in Korea: Incheon, an industrial area, and Jeju, a non-industrialized area.

Methods: Second grade students at elementary schools (11 schools in Incheon and 45 schools in Jeju) were examined in a cross-sectional study. A questionnaire was used and a skin prick test was performed. The levels of $\mathrm{NO}_{2}, \mathrm{CO}_{2}, \mathrm{O}_{3}$, particulate matter (PM) $\mathrm{PM}_{10 / 2.5}$, formaldehyde, tVOCs, and dust mites in the classrooms and grounds were determined.

Results: The levels of outdoor $\mathrm{CO}, \mathrm{PM}_{10}$, and $\mathrm{PM}_{2.5}$ were significantly higher in Incheon $(P<0.01)$. The levels of indoor $\mathrm{CO}, \mathrm{CO}_{2}, \mathrm{PM}_{10}, \mathrm{PM}_{2.5}$ were significantly higher in Incheon $(P<0.01)$. The prevalence rates of AR symptoms at any time, AR symptoms during the last 12 months, diagnosis of rhinitis at any time, and AR treatment during the last 12 months were significantly higher in Incheon $(P<0.01)$. The prevalence rate of wheezing or whistling at any time, and wheezing during the last 12 months were significantly higher in Incheon $(P<0.01)$.

Conclusion: We found that the children living in Incheon, which was more polluted than Jeju, had a higher rate of AR and asthma symptoms compared to children in Jeju. To determine the effect of air pollution on the development of the AR and asthma, further studies are needed.

Key words: Air pollution, Particulate matter, Prevalence, Asthma, Allergic rhinitis

This is an open-access article distributed under the terms of the Creative Commons Attribution Non-Commercial License (http://creativecommons.org/licenses/by$\mathrm{nc} / 3.0 /$ ) which permits unrestricted non-commercial use, distribution, and reproduction in any medium, provided the original work is properly cited.

\section{Introduction}

The prevalence of allergy-related diseases has increased over the last decades. A combination of environmental exposures and inherent biological and genetic vulnerabilities implicate allergy-related diseases ${ }^{1,2}$.
It is difficult to elucidate the relationship between air pollution and allergy-related diseases. Some studies have shown that exposure to air pollutants increases the response to aeroallergens ${ }^{3,4}$. One study has shown that respiratory-related allergies are more common in urban areas than in rural areas of industrialized countries ${ }^{4}$. There are also 
some reports that air pollution is strongly associated with the aggravation of asthma, visits to emergency centers, hospitalizations and medications, ${ }^{5,6)}$.

Previously, we found that a statistically significant relation between air pollutants [nitric oxide $\left(\mathrm{NO}_{2}\right)$, ozone $\left(\mathrm{O}_{3}\right)$, sulfur dioxide $\left(\mathrm{SO}_{2}\right)$ and particulate matter $(\mathrm{PM})$ of $10 \mu \mathrm{m}$ or less $\left.\left(\mathrm{PM}_{10}\right)\right]$ and the increased number of patients visiting the outpatient department and emergency center with respiratory diseases ${ }^{7,8)}$. From a study of 368 middle school students, we found that $\mathrm{PM}_{10}$ had adverse effects on forced expiratory volume in one second. By measuring the levels of biomarkers such as muconic acid and 1-OH pyrene, we also found that volatile organic compounds (VOCs) and polycyclic aromatic hydrocarbons (PAHs) play a role in the presentation of asthma ${ }^{9,10)}$.

Other studies, however, have suggested that there is little relation between air pollution and asthma. Nicolai and von Mutius ${ }^{11)}$ reported no significant difference in the prevalence of asthma in elementary school students between East Germany, an industrialized area, and West Germany, an urban area. In addition, Charpin et al. ${ }^{12)}$ reported that air pollution and atopy were not significantly related.

To analyze the relation between air pollution and allergy-related diseases, we investigated the levels of air pollutants and the prevalence of allergy-related diseases in Incheon, an industrialized area, and Jeju, a non-industrialized area.

\section{Materials and methods}

\section{Subjects}

This study was performed in Incheon and Jeju, Korea. Air pollution in Incheon originates mainly from the photochemical industry. Because there are three highways and an international airport in the district, exhaust from automobiles also contributes to air pollution. The air in Jeju, however, is not exposed to any major industrial plants. Second grade students from 56 elementary schools (11 schools in the metropolitan city of Incheon and 45 schools in the Seogwipo city, Jeju Special SelfGoverning Province) were enrolled in this study between October 6th, 2008 and December 5th, 2008. Written informed consent was provided by parents or guardians for all subjects. A modified version of the International Study of Asthma \& Allergies in Children (ISAAC) written questionnaire (1,315 students from Incheon and 1,829 from Jeju) regarding their history of allergy-related disease, environment, life style and diet was completed for all students by their parents or guardians. Of these, 89 students in Incheon and 81 students in Jeju were excluded because of insufficient completion. In addition, some of the students were submitted to a skin prick test (1,221 students from Incheon and 170 students from Jeju). The institutional review board of our hospital approved the study.

\section{Methods}

1) Measurement of air pollutants

From December 17th to December 24th, a single measurement from 13 elementary schools (11 schools in Incheon and 2 schools in Jeju) was performed during the same period. In Incheon 11 schools were selected evenly according to pre-examined PM levels. But in Jeju, one school was in urban area (Seogwipo city) and the other was rural area. In 13 elementary schools, the levels of $\mathrm{CO}, \mathrm{CO}_{2}, \mathrm{O}_{3}, \mathrm{NO}_{2}, \mathrm{PM}_{10 / 2.5}$, formaldehyde, total volatile organic compounds ( $\mathrm{t}-\mathrm{VOCs})$, house dust mites and endotoxins were checked indoors (i.e., in classrooms, cafeterias and infirmaries) and outdoors (i.e., at the playgrounds and rooftops of the schools). A Gray Wolf Sensing Solution IQ604 Indoor Air Quality Probe (GrayWolf Sensing Solutions, Shelton, CT, USA) was used to measure $\mathrm{CO}, \mathrm{CO}_{2}, \mathrm{O}_{3}, \mathrm{NO}_{2}$, temperature and humidity. $\mathrm{PM}_{10}$ and $\mathrm{PM}_{2.5}$ were measured using a GT-331 monitor (Met One Instruments Inc., Grants Pass, OR, USA) and formaldehyde was measured using a Formaldehyde Mater w/Pump Model Z- 300XP (Environmental Sensors Co., Boca Raton, FL, USA). A ppbRAE3000 (Rae Systems Inc., San Jose, CA, USA) was used to measure t-VOC, and mite kits were used to measure house dust mites.

\section{2) Skin prick tests}

In Incheon, 12 common allergen extracts (Allergopharma, Reinbeck, Germany) were measured, including grass, trees I mixture (alder, hazel, poplar, elm, and willow), trees II mixture (birch, beech, oak, and plane tree), mugwort, ragweed, Dermatophagoides farinae, Dermatophagoides pteronyssinus, cockroaches, Aspergillus furmigatus, molds I mixture (alternaria, botrytis, cladosporium, curvularia, fusarium, helminthosporium), molds II mixture (aspergillus, mucor, penicillium, pullularia, rhizopus, and serpula), dog hair, cat fur. Histamine and isotonic saline were used as positive and negative controls, respectively. In Jeju, cedar, citrus red mite, hop japanese pollens and Tyrophagus were added to the 12 allergen extracts used in Incheon.

After a drop of allergen extracts, the skin was pricked through the drop using the tip of a lancet and then wiped cautiously. After 15 minutes, we measured the size of the wheal and erythema. Positive results were recorded if the size of the wheal was larger than the positive control $^{13,144)}$.

\section{Statistical analysis}

Data are presented as means \pm standard deviations ( $\mathrm{SDs}$ ) or as geometric means and a range of $1 \mathrm{SD}$. Statistical analysis for the levels of air pollutants and pulmonary function test were performed using Student's $t$-test. AX2 test was used to analyze the prevalence of allergy related diseases and the skin prick test. All calculations were performed 
with the SPSS ver. 12.0 (SPSS Inc., Chicago, IL, USA). A probability value of less than 0.05 was considered statistically significant.

\section{Results}

\section{Anthropometric measurements}

The children's mean height in Incheon was $128.7 \pm 5.9 \mathrm{~cm}$ and $129.3 \pm$ $6.0 \mathrm{~cm}$ in Jeju. The children's mean weight was $28.4 \pm 6.1 \mathrm{~kg}$ and $29.6 \pm$ $6.2 \mathrm{~kg}$ in Incheon and Jeju, respectively. The mean body mass index (BMI) percentiles in the children from Incheon was $110.6 \pm 19.2 \%$ vs. $114.7 \pm 19.5 \%$ in the children from Jeju. We found no significant differences in any of the anthrometric measurements between Incheon and Jeju students [height $(P=0.36)$, weight $(P=0.07)$ and BMI percentiles $(P=0.17)]$ (Table 1$)$.

\section{Level of indoor and outdoor air pollutants at the} elementary schools

In outdoor measurements, the levels of $\mathrm{CO}, \mathrm{PM}_{10}$ and $\mathrm{PM}_{2.5}$ in Incheon were higher than those in Jeju $(0.4114 \pm 0.0735 \mathrm{ppm}, 52.37 \pm 5.78 \mu \mathrm{g} /$ $\mathrm{m}^{3}, 14.30 \pm 2.25 \mu \mathrm{g} / \mathrm{m}^{3}$, respectively, in Incheon vs. $0.0975 \pm 0.0448$ ppm, $20.00 \pm 2.28 \mu \mathrm{g} / \mathrm{m}^{3}, 4.10 \pm 0.10 \mu \mathrm{g} / \mathrm{m}^{3}$, respectively, in Jeju).

Table 1. The Characteristics and Anthropometric Measurements of Second Grade Elementary Students

\begin{tabular}{lccc}
\hline Variable & Incheon $(\mathrm{n}=1,226)$ & Jeju $(\mathrm{n}=1,748)$ & $P$ value $^{\star}$ \\
\hline Age (yr) & $9.2 \pm 0.1$ & $9.0 \pm 0.2$ & $<0.01$ \\
Sex (Male/Female) & $612 / 614$ & $876 / 872$ & 0.91 \\
Parental history of asthma & $306(24.96)$ & $328(18.80)$ & $<0.01$ \\
Parental history of AR & $592(48.34)$ & $630(36.05)$ & $<0.01$ \\
Height (cm) & $128.7 \pm 5.9$ & $129.3 \pm 6.0$ & 0.36 \\
Weight (kg) & $28.4 \pm 6.1$ & $29.6 \pm 6.2$ & 0.17 \\
BMl percentiles & $110.6 \pm 19.2$ & $114.7 \pm 19.5$ & 0.17 \\
\hline
\end{tabular}

Values are presented as mean \pm SD or number (\%).

$A R$, allergic rhinitis; BMl, body mass index.

${ }^{*}$ Calculated by $t$-test \& chi-square test.

Table 2. Comparison of Elementary School Outdoor Air Pollutants in Incheon and Jeju

\begin{tabular}{lccc}
\hline Variable & Incheon $(\mathrm{n}=22)$ & Jeju $(\mathrm{n}=4)$ & $P$ value \\
\hline $\mathrm{CO}(\mathrm{ppm})$ & $0.41 \pm 0.34$ & $0.10 \pm 0.08$ & 0.08 \\
$\mathrm{CO}_{2}(\mathrm{ppm})$ & $393.15 \pm 48.88$ & $384.58 \pm 30.94$ & 0.71 \\
$\mathrm{HCHO}\left(\mu \mathrm{g} / \mathrm{m}^{3}\right)$ & $28.64 \pm 65.26$ & $10.00 \pm 0.00$ & 0.33 \\
$\mathrm{NO}_{2}(\mathrm{ppm} \times 100)$ & $0.87 \pm 0.17$ & $2.18 \pm 0.80$ & 0.20 \\
$\mathrm{O}_{3}(\mathrm{ppm} \times 100)$ & $1.14 \pm 0.18$ & $2.30 \pm 0.63$ & 0.02 \\
$\mathrm{PM}_{10}\left(\mu \mathrm{g} / \mathrm{m}^{3}\right)$ & $52.37 \pm 5.78$ & $20.00 \pm 2.28$ & $<0.01$ \\
$\mathrm{PM}_{2.5}\left(\mu \mathrm{gg} / \mathrm{m}^{3}\right)$ & $14.30 \pm 2.25$ & $4.10 \pm 0.10$ & $<0.01$ \\
\hline
\end{tabular}

Values are presented as mean \pm SD.

$\mathrm{HCHO}$, formaldehyde; $\mathrm{PM}$, particulate matter.

${ }^{*}$ Calculated by Student's $t$-test.
Ozone levels were higher in Jeju $(0.0230 \pm 0.0063 \mathrm{ppm})$ (Table 2). In indoor measurements, the levels of $\mathrm{CO}, \mathrm{CO}_{2}, \mathrm{PM}_{10}, \mathrm{PM}_{2.5}, \mathrm{t}$-VOC were higher in Incheon than in Jeju $(1.2525 \pm 0.0812$ ppm, 2,001.6 \pm 100.4 ppm, $154.20 \pm 13.02 \mu \mathrm{g} / \mathrm{m}^{3}, 17.78 \pm 1.47 \mu \mathrm{g} / \mathrm{m}^{3}$, and $226.25 \pm 62.74 \mu \mathrm{g} /$ $\mathrm{m} 3$ vs. $0.5317 \pm 0.1428 \mathrm{ppm}, 1,038.5 \pm 102.2 \mathrm{ppm}, 59.36 \pm 5.86 \mu \mathrm{g} / \mathrm{m}^{3}$, $5.61 \pm 0.68 \mu \mathrm{g} / \mathrm{m}^{3}, 64.51 \pm 36.85 \mu \mathrm{g} / \mathrm{m}^{3}$, respectively) (Table 3).

\section{Prevalence of allergic rhinitis (AR) and asthma as determined by written questionnaire}

The prevalences of "sneezing or blocked nose without a cold or flu, ever", "sneezing or blocked nose without a cold or flu, last 12 months", "diagnosis of rhinitis, ever", "treatment of AR, last 12 months", and "treatment of non-AR, last 12 months" in Incheon were 48.34\%, $44.44 \%, 34.13 \%, 27.42 \%$, and $35.92 \%$ significantly higher than in Jeju $36.05 \%, 28.69 \%, 20.02 \%, 14.59 \%$, and $17.08 \%$. The prevalences of "wheeze or whistling ever", and "wheezing, last 12 months" in Incheon were $24.80 \%$ and $9.50 \%$ significantly higher than in Jeju $18.80 \%$, and $6.83 \%$ (Table 4 ).

\section{Sensitization to allergens}

The sensitization rate to $D$. farinae was significantly different between Incheon and Jeju ( $24.58 \%$ vs. $31.40 \%, P=0.03)$. Statistical analysis was not possible for most allergens, except for house dust mites (Table 5).

\section{Discussion}

We found that the children living in Incheon, which was polluted with higher levels of PM had a higher prevalence of the symptoms of AR and asthma compared to children in Jeju. During the last decade,

Table 3. Comparison of Elementary School Indoor Air Pollutants in Incheon and Jeju

\begin{tabular}{lccc}
\hline Variable & Incheon $(\mathrm{n}=71)$ & Jeju $(\mathrm{n}=6)$ & $P$ value $^{*}$ \\
\hline $\mathrm{TSB}\left(\mathrm{CFU} / \mathrm{m}^{3}\right)$ & $777.72 \pm 52.89$ & $559.17 \pm 146.97$ & 0.24 \\
$\mathrm{CO}(\mathrm{ppm})$ & $1.25 \pm 0.08$ & $0.53 \pm 0.14$ & $<0.01$ \\
$\mathrm{CO}_{2}(\mathrm{ppm})$ & $2,001.6 \pm 100.4$ & $1,038.5 \pm 102.2$ & $<0.01$ \\
$\mathrm{HCHO}\left(\mu \mathrm{g} / \mathrm{m}^{3}\right)$ & $279.44 \pm 23.83$ & $196.67 \pm 87.31$ & 0.33 \\
Humidity $(\%)$ & $48.41 \pm 1.57$ & $43.69 \pm 4.02$ & 0.39 \\
$\mathrm{NO}_{2}(\mathrm{ppm})$ & $0.02 \pm 0.03$ & $0.03 \pm 0.03$ & 0.31 \\
$\mathrm{O}_{3}(\mathrm{ppm})$ & $0.02 \pm 0.02$ & $0.03 \pm 0.02$ & 0.30 \\
$\mathrm{PM}_{10}\left(\mu \mathrm{gg} / \mathrm{m}^{3}\right)$ & $154.20 \pm 13.02$ & $59.36 \pm 5.86$ & $<0.01$ \\
$\mathrm{PM}_{2.5}\left(\mathrm{\mu g} / \mathrm{m}^{3}\right)$ & $17.78 \pm 1.47$ & $5.61 \pm 0.68$ & $<0.01$ \\
$\mathrm{~T}-\mathrm{VOC}\left(\mu \mathrm{gg} / \mathrm{m}^{3}\right)$ & $226.25 \pm 62.74$ & $64.51 \pm 36.85$ & 0.03 \\
Temp $\left({ }^{\circ} \mathrm{C}\right)$ & $17.5 \pm 0.3$ & $17.0 \pm 0.8$ & 0.66 \\
\hline
\end{tabular}

Values are presented as mean \pm SD.

$\mathrm{TSB}$, total suspended bacteria; $\mathrm{HCHO}$, formaldehyde; $\mathrm{PM}$, particulate matter; TVOC, total volatile organic compound.

${ }^{*}$ Calculated by Student's $t$-test. 
Table 4. Prevalence of Allergy According to the ISAAC Questionnaire

\begin{tabular}{lccc}
\hline Variable & $\begin{array}{c}\text { Incheon } \\
(\mathrm{n}=1,226)\end{array}$ & $\begin{array}{c}\text { Jeju } \\
(\mathrm{n}=1,748)\end{array}$ & $P$ value $^{*}$ \\
\hline AR symptoms, ever & $583(48.34)$ & $620(36.05)$ & $<0.01$ \\
AR symptoms, last 12 mo & $527(44.44)$ & $480(28.69)$ & $<0.01$ \\
Diagnosis of AR, ever & $412(34.13)$ & $346(20.02)$ & $<0.01$ \\
Treatment of AR, last 12 mo & $329(27.42)$ & $249(14.59)$ & $<0.01$ \\
Treatment of non-AR, last 12 mo & $431(35.92)$ & $293(17.08)$ & $<0.01$ \\
Treatment of sinusitis, last 12 mo & $174(14.51)$ & $199(11.66)$ & 0.02 \\
Wheeze or whistling, ever & $304(24.96)$ & $321(18.80)$ & $<0.01$ \\
Wheezing, last 12 mo & $116(9.50)$ & $115(6.83)$ & $<0.01$ \\
Diagnosis of asthma, ever & $159(13.13)$ & $230(13.38)$ & 0.47 \\
Treatment of asthma, last 12 mo & $50(4.19)$ & $64(3.78)$ & 0.57 \\
\hline
\end{tabular}

Values are presented as number (\%).

ISAAC, International Study of Asthma \& Allergies in Children; Allergic rhinitis (AR) symptoms was defined as sneezing or blocked nose without a cold or flu.

${ }^{*}$ Calculated by chi-square tests.

Table 5. Skin Test Positivity

\begin{tabular}{lccc}
\hline & $\begin{array}{c}\text { Incheon } \\
(n=1,221)\end{array}$ & $\begin{array}{c}\text { Jeju } \\
(\mathrm{n}=170)\end{array}$ & $P$ value \\
\hline Dermatophagoides farinae & 24.58 & 31.40 & 0.03 \\
Dermatophagoides pteronyssinus & 25.85 & 32.56 & 0.07 \\
\hline
\end{tabular}

Values are presented as percentage.

${ }^{*}$ Calculated by chi-square tests.

the respective annual mean airborne $\mathrm{PM}_{10}$ levels in Incheon and Jeju were $57 \mu \mathrm{g} / \mathrm{m}^{3}$ vs. $38 \mu \mathrm{g} / \mathrm{m}^{3}$ in 2002, $61 \mu \mathrm{g} / \mathrm{m}^{3}$ vs. $35 \mu \mathrm{g} / \mathrm{m}^{3}$ in $2003,62 \mu \mathrm{g} / \mathrm{m}^{3}$ vs. $40 \mu \mathrm{gg} / \mathrm{m}^{3}$ in $2004,61 \mu \mathrm{g} / \mathrm{m}^{3}$ vs. $42 \mu \mathrm{g} / \mathrm{m}^{3}$ in $2005,68 \mu \mathrm{g} / \mathrm{m}^{3}$ vs. $45 \mu \mathrm{g} / \mathrm{m}^{3}$ in 2006, and $64 \mu \mathrm{g} / \mathrm{m}^{3}$ vs. $39 \mu \mathrm{g} / \mathrm{m}^{3}$ in $2007^{15)}$. The level of airborne $\mathrm{PM}_{10}$ in Incheon has been consistently higher than in Jeju over the last decade. This is consistent with our measurements. Traffics from diesel trucks and buses on the roads contribute a large proportion of $\mathrm{PM}_{10}$ level in urban areas ${ }^{16)}$, and three express highways cross the Incheon area. Airborne PM less than $10 \mu \mathrm{m}$ in aerodynamic diameter $\left(\mathrm{PM}_{10}\right)$ is a complex mixture of materials having a carbonaceous core and associated materials such as organic compounds, acids, and fine particles of metals ${ }^{17)} \cdot \mathrm{PM}_{10}$ or diesel extract particles augment lung inflammation by inhalant allergens or respiratory viral infection via acting as an adjuvant. The response may lead to enhancement of already existing allergies or immunoglobulin E response to neoallergens and susceptibility to respiratory infection. This adjuvant effect is exerted by the enhanced production of inflammatory Th2 and/or Th1 cytokines ${ }^{18,19)}$.

Choudhury et al. ${ }^{20)}$ reported that a significant positive association between asthma morbidity and $\mathrm{PM}_{10}$ pollution was observed. This finding also support the hypothesis that air pollution, at levels below the current ambient air quality standards is harmful to sensitive subjects, such as asthmatic children. In this study, the level of outdoor ozone was higher in Jeju than in Incheon. However, the prevalence of allergyrelated symptoms was not higher in children living in Jeju compared to those in Incheon. Thus, we can conclude that airborne PM and not ozone primarily influences development and aggravation of allergyrelated symptoms.

ISAAC, which Korea joined in 1995, has enabled us to compare prevalence between countries. Korea has participated in three ISAAC surveys: two nationwide surveys in 1995 and 2000, and one regional survey in Seoul city in 2005. According to the survey results of Seoul city, the last 12-month prevalence of wheezing decreased from $10.5 \%$ in 1995 to $5.2 \%$ in 2000 , and then to $5.5 \%$ in 2005 ; the lifetime prevalence of asthma diagnosis has been relatively constant: $8.7 \%$ in $1995,9.4 \%$ in 2000 , and $7.6 \%$ in 2005 ; the lifetime prevalence of AR diagnosis has increased $16.8 \%$ in $1995,22.0 \%$ in 2000, 26.4\% in $2005^{21-233}$. According to previous study in the Songpa area of Seoul in 2008, the prevalence of AR symptoms ever was $42.5 \%$, AR symptoms during the last 12 months was 39.0\%, AR diagnosis from the doctor was $38.5 \%$, treatment of AR, last 12 months was $29.5 \%$. This is consistent with our results in Incheon ${ }^{24)}$.

The prevalence of allergic diseases tends to be lower in rural areas, which may have high exposure rates to microbial environments, than in urban areas ${ }^{25)}$.

In our study, the number of enrolled students in the skin prick test in Jeju is lower than in Incheon. So it is difficult to compare the atopic status of both area. But the most common allergens identified by skin prick tests in Korean students are house dust mites. And the sensitization rate of house dust mite in Jeju corresponds with the results of a recent study $^{26)}$. Thus we could compare atopic status of both area. We found that the sensitization rate of children to house dust mites ( $D$. farinae and $D$. pteronyssinus) was lower in Incheon children compared to Jeju children. This finding does not correspond with the results of a recent study, which reported that the sensitization rate was higher in Seoul than in Jeongeup ${ }^{27}$. Ahn and $\mathrm{Choi}^{28)}$ reported that, in 661 randomly selected 6 to 12 years old children at a school in Seoul, the positive skin reaction rates were $40.7 \%$ for $D$. pteronyssinus and $44.3 \%$ for $D$. farinae. Yang et al. ${ }^{29)}$ reported a skin prick positivity of $D$. farinae (20.4\%) and house dust (14.7\%). Lee et al..$^{30)}$ reported that the prevalence of skin reactivity in $D$. pteronyssinus and $D$. farinae was $17.0 \%$ and $15.5 \%$, respectively, in a group of 6 to 8 years old. In addition, in rural areas of Jeju island, the sensitization rates to $D$. pteronyssinus and $D$. farinae, among the younger age groups (7 to 12 years) were $20.6 \%$ and $24.4 \%$, respectively ${ }^{311}$. The results of the skin test among young medical students in Seoul with or without respiratory allergy or, atopy were present for $D$. pteronyssinus $37.9 \%$, and $D$. farinae $35.7 \%{ }^{322}$.

In this study, we found that the increase of $\mathrm{PM}_{10 / 2.5}$ could be asso- 
ciated with the development and aggravation of AR and asthma in children, independent of allergic sensitization.

The small number of enrolled students in the skin prick test in Jeju is a limitation. Thus we cannot claim a definitive association between air pollution and atopic status of the children living in the different communities. In the near future, we will continue this comparison study to elucidate the relationship between air pollution and allergyrelated disease. In this cross-sectional analysis, the children living in Incheon, who were exposed to a higher level of outdoor $\mathrm{PM}_{10 / 2.5}$ and $\mathrm{CO}$ than children living in Jeju, showed more allergy-related symptoms by questionnaire.

In conclusion, in the area of higher air pollutants such as $\mathrm{CO}, \mathrm{PM}_{10}$ and $\mathrm{PM}_{2.5}$, the higher prevalence of allergy by questionnaire such as AR symptoms, diagnosis rate and treatment rate and asthma symptoms was found. Further studies are needed to elucidate the relationship between air pollution and allergy-related disease.

\section{Acknowledgement}

This work was supported by Ministry of Environment, Korea and Inha University.

\section{References}

1. Martinez FD. Toward asthma prevention: does all that really matters happen before we learn to read? N Engl J Med 2003;349:1473-5.

2. Duffy DL, Mitchell CA, Martin NG. Genetic and environmental risk factors for asthma: a cotwin-control study. Am J Respir Crit Care Med 1998;157:840-5.

3. Riedler J, Eder W, Oberfeld G, Schreuer M. Austrian children living on a farm have less hay fever, asthma and allergic sensitization. Clin Exp Allergy 2000;30:194-200.

4. Braun-Fahrländer C, Gassner M, Grize L, Neu U, Sennhauser FH, Varonier HS, et al. Prevalence of hay fever and allergic sensitization in farmer's children and their peers living in the same rural community. SCARPOL team. Swiss Study on Childhood Allergy and Respiratory Symptoms with Respect to Air Pollution. Clin Exp Allergy 1999;29:28-34.

5. Sunyer J, Sáez M, Murillo C, Castellsague J, Martínez F, Antó JM. Air pollution and emergency room admissions for chronic obstructive pulmonary disease: a 5-year study. Am J Epidemiol 1993;137:701-5.

6. Atkinson RW, Anderson HR, Strachan DP, Bland JM, Bremner SA, Ponce de Leon A. Short-term associations between outdoor air pollution and visits to accident and emergency departments in London for respiratory complaints. Eur Respir J 1999;13:257-65.

7. Choi H, Lim DH, Kim JH, Son BK, Lim JW. Study on the interrelationship of air pollution and respiratory diseases in inchon city via children who visited the emergency room of Inha University Hospital. J Korean Pediatr Soc 2000;43:1372-9.

8. Kang SK, Lim DH, Kim JH, Son BK, Lim JW, Hong YC. Relationship of air pollution and pediatric respiratory diseases in Incheon city. Pediatr Allergy Respir Dis 2001;11:354-62.
9. Kim JH, Lim DH, Kim JK, Jeong SJ, Son BK. Effects of particulate matter (PM10) on the pulmonary function of middle-school children. J Korean Med Sci 2005;20:42-5.

10. Kim JH, Kim JK, Son BK, Oh JE, Lim DH, Lee KH, et al. Effects of air pollutants on childhood asthma. Yonsei Med J 2005;46:239-44.

11. Nicolai T, von Mutius E. Pollution and the development of allergy: the East and West Germany story. Arch Toxicol Suppl 1997;19:201-6.

12. Charpin D, Pascal L, Birnbaum J, Armengaud A, Sambuc R, Lanteaume A, et al. Gaseous air pollution and atopy. Clin Exp Allergy 1999;29:1474-80.

13. Ownby DR. Skin tests in comparison to other diagnostic methods. Immunol Allergy Clin North Am 2001;21:355-67.

14. Tripathi A, Patterson R. Clinical interpretation of skin test results. Immunol Allergy Clin North Am 2001;21:291-300.

15. Air Korea. Real-time ambient air quality dissemination system [Internet]. Incheon: Korea Environment Corporation; c2010 [cited 2010 Sep 5]. Available from: http://www.airkorea.or.kr.

16. Fraser MP, Yue ZW, Buzcu B. Source apportionment of fine particulate matter in Houston, TX, using organic molecular markers. Atmos Environ 2003;37:2117-23.

17. Pagan I, Costa DL, McGee JK, Richards JH, Dye JA. Metals mimic airway epithelial injury induced by in vitro exposure to Utah Valley ambient particulate matter extracts. J Toxicol Environ Health A 2003;66:1087-112.

18. Diaz-Sanchez D, Tsien A, Fleming J, Saxon A. Combined diesel exhaust particulate and ragweed allergen challenge markedly enhances human in vivo nasal ragweed-specific IgE and skews cytokine production to a T helper cell 2-type pattern. J Immunol 1997;158:2406-13.

19. Fujieda S, Diaz-Sanchez D, Saxon A. Combined nasal challenge with diesel exhaust particles and allergen induces In vivo IgE isotype switching. Am J Respir Cell Mol Biol 1998;19:507-12.

20. Choudhury AH, Gordian ME, Morris SS. Associations between respiratory illness and PM10 air pollution. Arch Environ Health 1997;52:113-7.

21. Hong SJ, Ahn KM, Lee SY, Kim KE. The prevalences of asthma and allergic diseases in Korean children. Korean J Pediatr 2008;51:343-50.

22. Lee SI. Prevalence of childhood asthma in Korea: international study of asthma and allergies in childhood. Allergy Asthma Immunol Res 2010;2: 61-4.

23. Hong SJ. Epidemiology of childhood asthma and allergic diseases. Pediatr Allergy Respir Dis 2007;17:S55-66.

24. Kwon JW, Seo JH, Yu J, Kim BJ, Kim HB, Lee SY, et al. Relationship between the prevalence of allergic rhinitis and allergen sensitization in children of Songpa area, Seoul. Pediatr Allergy Respir Dis(Korea) 2011;21:47-55.

25. Alfvén T, Braun-Fahrländer C, Brunekreef B, von Mutius E, Riedler J, Scheynius A, et al. Allergic diseases and atopic sensitization in children related to farming and anthroposophic lifestyle: the PARSIFAL study. Allergy 2006;61:414-21.

26. Kim J, Hahm MI, Lee SY, Kim WK, Chae Y, Park YM, et al. Sensitization to aeroallergens in Korean children: a population-based study in 2010. J Korean Med Sci 2011;26:1165-72.

27. Jung HH, Kwon JW, Lee SY, Seo JH, Song YH, Kim BJ, et al. Correlation between demographic characteristics and indoor allergen sensitization among Jeongeup countryside, Jeongeup city, and Seoul city in Korea. Korean J Asthma Allergy Clin Immunol 2010;30:277-84.

28. Ahn YM, Choi EY. The result of skin prick tests with 9 common aeroallergen in Korea and RAST reactivity to D. farinae in a community school children. 
Allergy 1990;10:213-25.

29. Yang SY, Na MJ, Choi WH, Kim KW. A result of allergic skin test by several common inhalant allergens in pediatric age group. J Korean Pediatr Soc 1989;32:223-9.

30. Lee SI, Moon HN, Min MH, Kim DS, Jeon BH. The prevalence of immediate positive skin tests to house dust related allergens in Korean community population. Allergy 1992;12:285-90.
31. Lee MH, Hong SC, Kim SH, Bahn JW, Kim TB, Kim YK, et al. Prevalence of asthma and atopy in children living in rural areas of Cheju island for an interval of three years. J Asthma Allergy Clin Immunol 2002; 22:85-91.

32. Kwak HJ, Kim SH, Kim TH, Sohn JW, Shin DH, Park SS, et al. Prevalence of sensitization rates to inhalant allergens and airway hyperresponsiveness among medical students in Seoul. Korean J Asthma Allergy Clin Immunol 2009;29:166-70. 